\title{
DIE AFRIKAANSE VOLKSKULTUUR EN DIE
}

\author{
NUWE WERELD
}

Die opskrif dwing die referent om te opereer met twee begrippe wat deur hulle kompleksiteit en onbelyndheid uiters moeilik bepaalbaar en hanteerbaar is. Alhoewel sommige strominge in die moderne Volkekunde die reg van hierdie wetenskap erken om alle volkskulture, ook dié van die moderne volke te bestudeer, het weinig skrywers hulle energie en vaardigheid in hierdie rigting gewaag. Dit is trouens juis die begrensdheid, homogeniteit en betreklike eenvoud van die primitiewe volkskulture wat die beoefenaars van die vak in die praktyk gedwing en verlei het om hulle aandag feitlik uitsluitend op sodanige kultuurstudies toe te spits. Die studie van die grotere en moderne volke is links gelaat aangesien die getalsterkte, interne verskeidenheid en snelle veranderinge byna onoorkoomlike eise aan die navorser stel.

In die geval van die Afrikaanse volkskultuur is dit om verskeie redes des te moeiliker, vanweë 'n sekere onbepaaldheid in die voorwerp. Verskeie pogings is reeds in hierdie rigting aangewend. Benewens die waardevolle resultate daarvan is daar m.i. nog nie een wat werklik groot welslae behaal het nie. Die meeste ly aan enkele leemtes: 'n neiging tot veralgemening met 'n redelike tikkie romantisering of idealisering daarin en ten tweede 'n gebrek aan duidelike onderskeiding tussen wat "tipies" Afrikaans sou wees, d.w.s. geheel onderskeie van ander volkskulture, en meesal ook 'n verwarring van wat tot die volksaard en wat tot die volkskultuur behoort. ' $n$ Afrikaanse etnografiese studie bestaan daar nog nie.

'n Volkskultuur is op sy eenvoudigste 'n komplekse entiteit. Omdat kultuur, soos 'n volk, in 'n gedurige proses begrepe is, kan 'n volkskultuur wesenlik eintlik alleen beskrywe word ten opsigte van 'n bepaalde tydstip. Dit word na verhouding makliker wanneer die kultuur aan geringe veranderinge onderworpe is, m.a.w. sterker tradisiegebonde is en neig na 'n statiese toestand. Dit word uiteraard moeiliker indien die volkskultuur in ' $n$ vinnige en intensiewe veranderingsproses begrepe is, waarin selfs die tradisie of historiese 
gestalte met sy vorme en norme feitlik van dag tot dag gewysig word. Te meer is dit die geval as 'n volkskultuur nog nouliks ' $n$ herkenbare konfigurasie, gestalte of vorm aangeneem het en die patroon wat die geheel in sy interne verskeidenheid onderlê, nie duidelik onderskei kan word nie.

Die vraag is of daar reeds in Suid-Afrika 'n Afrikaanse volkskultuur duidelik uitgekristalliseer het. Nieteenstaande wat dikwels aanvaar word nl. dat die Afrikaner dermate in isolasie verkeer het dat hy 'n duidelik eie en onderskeibare volkskultuur voortgebring het, wil ek beweer dat die siening slegs gedeeltelik realisties is. Dit mag grootliks so gewees het gedurende die anderhalwe eeu van die volksplanting af, maar sedert die begin van die agtiende eeu is die isolasie verbreek. Hiermee word verwys na die kontak met ander min of meer histories, godsdienstig en etnies verwante Europese volkskulture wat vandag nog voortgesit word deur noue aanraking met die Anglo-Saksiese kultuur, met Europese immigrantegroepe en, veral deur die toedoen van die kommunikasiemedia, met die Amerikaanse kultuur.

Aan die Afrikaanse volkskultuur is tot aan die einde van die negentiende en selfs tot vroeg in die twintigste eeu heelwat aandag gegee. Maar wat toe, selfs tereg as Afrikaanse kultuur aangedui en beskryf is, is bowendien nie meer noodwendig die Afrikaanse volkskultuur van die jaar 1969 nie. Selfs sonder dat die "volkskarakter" - ook 'n wesenlik nog onbepaalde en moeilik bepaalbare entiteit - gewysig hoef te wees, het die sosiologiese omstandighede sò verander dat 'n volledige vergelyking van die Afrikaanse volkskultuur van 1899 met die van 1969 - om maar twee datums te noem baie belangrike verskille sal aantoon. Dit is m.i. die kardinale fout in Bosman se poging om die Franse bydrae tot die Afrikaanse kultuur te beskryf (V. d. Heever en Pienaar), dat hy „volkskarakter" en kultuur sodanig verwar het dat daar weinig geldigs in sy konklusie steek.

Sosiologiese omstandighede het gedurende die afgelope halfeeu sodanig verander dat dit 'n byna onherkenbare "nuwe" kultuur te voorskyn gebring het, en derhalwe 'n kultuur wat deur heelparty ouere volkslede as volksvreemd en onafrikaans beskou word. Die groot trek na die stede het selfs die benaming Boerevolk uitgewis. Daardie kultuurkenmerke wat aanwesig, selfs opmerklik aanwesig, was onder landelike om- 
standighede soos gasvryheid, indiwidualisme, selfstandigheid en wat maklik as "tipiese" of „eie" Afrikaanse kultuur- en karaktertrekke aangedui is, ontbreek in 'n stedelike lewenswyse, nie omdat die volkskarakter of -aanleg verander het nie, maar omdat die volksgedrag en die -kultuur, omdat die nuwe milieu anders is. Kultuur is immers tot ' $n$ groot mate die resultaat van omgewingsbeheersing, die skepping van 'n sekondêre omgewing. Maar 'n landelike omgewing word anders beheers as 'n stedelike. Die lewe van die boer is anders as die van die industriewerker, die sakebestuurder, die finansbaas, die klerk en die tikster.

Gevolglik is die Afrikaanse volkskultuur van vandag reeds anders as dié van ons ouers, selfs as die van ons kinderdae, ten minste die kinderdae van ons oueres. Daarom is dit veral so moeilik om te sê wat is tipies Afrikaans en selfs gevaarlik om breed en lank te praat oor eg-Afrikaans of volksvreemd en dergelike terme. Bepaalde kultuurtrekke mag sterk geaksentueerd wees, maar dit sou gevaarlik onjuis wees om bv. gasvryheid of selfs algemene godsdienstigheid as 'n egAfrikaanse of eie of tipiese Afrikaanse kenmerk aan te dui, terwyl dit as verskynsels meesal deel is van agrariese kulture en selfs van eenvoudige gemeenskappe. Dit is die uitingsvorme van hierdie verskynsels wat 'n plek vind in die kultuurbeskrywing. 'n Bepaalde toevoeging mag onbekend wees aan die tradisie; dit bly slegs volksvreemd solank dit nie deur die volk aanvaar is nie. Die Mauser was "volksvreemd" in ' $n$ gemeenskap wat net snaphane geken het, maar het werklik nie lank volksvreemd gebly nie, al was dit in oorsprong nie „eg-Afrikaans" nie.

Onder die makliker waarneembare morfologiese kors van die volkskultuur, lê 'n moeiliker bepaalbare essense van lewenshoudinge en waardes, die sedes wat finaliter gegrond is in ' $n$ religieuse bodem. Meesal is die uitwendige die meer veranderlike en veranderbare en die onderliggende die normatiewe en vormgewende. Ten einde die toekoms en veral die roeping van 'n bepaalde volkskultuur te bepaal, moet die aandag afgewend word van die morfologiese en gevestig word op die grondliggende daarin soos uitgedruk in die basiese waardestruktuur en siftingsisteem. Dit vereis in die onderhawige geval ' $n$ deeglike analise van die begrip Christeliknasionaal. Hoe moet hierdie algemene term in die huidige 
Afrikaanse situasie in spesifieke begrippe beskryf en aangedui word?

Betreffende die primêr kwalifiserende term Christelik moet eerstens gevra word in hoeverre dit nog 'n algemene geldige kwalifikasie van die Afrikaanse kultuur verteenwoordig. Deur watter gedeelte van die volk word dit nog bewustelik anvaar as die basiese vormgewende norm van die kultuurlewe? Die vraag is selfs ook al ter sake in hoeverre dit slegs nog onbewustelik deur die tradisie die volksinstellinge en gedragwyses karakteriseer.

Die tweede vraag in hierdie verband is: watter besondere Christelike stempel dra die Afrikaanse volkskultuur vir soverre dit dan nog Christelik georiënteer is? Daarmee word reeds die erkenning gedoen dat Christelik in die praktyk van die volkslewe nie meer ' $n$ eenduidige konnotasie bevat nie. Is dit oorwegend Katoliek of Protestants? Hierop is die antwoord betreklik maklik te gee $\mathrm{nl}$. dat, nieteenstaande toenemende Rooms-Katolieke invloed, die Protestantse oriëntasie nog die sterkste is. Dit lê in lyn met die historiese agtergrond van die Afrikaner.

Die vraag of Christelik en Protestants selfs in die algemeen vertaal kan word met Gereformeerd of Calvinisties, is moeiliker te beantwoord. Gedurende die werklike vormingsjare van die Afrikanervolk was die Calvinisme verreweg die sterkste bepalende faktor. Die Lutherse inwerking was gering. Die Nederlandse Calvinistiese erfenis uit die jare volgende op die Dordtse sinode is veral kwantitatief versterk en gestempel deur die koms en die bydrae van die Franse Hugenote. Terwyl die Gereformeerde religie by baie van die Nederlandse koloniste, veral die ambagslui, dikwels bloot nominaal was, was die Hugenote deur die bank mense wat ter wille van daardie geloof die groot opoffering van 'n landverhuising gemaak het.

Die einde van die agtiende eeu het egter ook 'n ander Nederlandse godsdienstige erfenis na Suid-Afrika gebring $\mathrm{nl}$. die gehumaniseerde en vrysinnige belydenis. Dit is van die negentiende eeu af aangevul en versterk deur die koms van die Britte as draers van ò ' $n$ Rooms- of ' $n$ Metodisties-georiënteerde Protestantse geloof. Hierdie belydenis-koalisie word reeds vir etlike dekades in Suid-Afrika aangevul uit die Amerikaanse Christendom. In die lig van hierdie gebeure is 
dit nie onrealisties nie om te beweer dat die Calvinisme in die praktyk, hetsy bewustelik, hetsy tradisioneel en vormlik lankal nie meer die enigste religieuse wortel van die Afrikaanse kultuur is nie. Dit is selfs twyfelagtig of dit nog die oorwegende is.

Die gewig van 'n bepaalde belydenis t.o.v. die kultuurgeheel of -patroon, hoef nie volkome eweredig te wees tot die getalsverhouding van sy draers nie. Dit hang veel meer af van die status, posisie, invloed en geloofsintensiteit van die belyers. In 'n demokratiese wêreld of deur die monopolisering van die massamedia kan hierop ook meer invloed uitgeoefen word as wat die werklike aanhangers van 'n bepaalde kultuur of belydenis regverdig.

Die tweede lid van die koppelwoord Christelik-nasionaal moet uiteraard aangedui word as Afrikaans. Tog is die inhoud daarvan moeiliker vas te pen as dié van die term Christelik. Dit is die meer subjektiewe, relatiewe en veranderlike gedeelte van die term. Wat Afrikaans in elke gegewe geval is, moet bepaal word deur 'n maatstaf en lg. moet uiteraard gevind word of in 'n algemene ideaal of in wat in die verlede as sodanig gegeld het. In alle geval moet altyd in gedagte gehou word dat geen kultuur in elke opsig van ander kulture verskil nie. Die alledaagse kultuuruitinge is in elk geval die mees veranderlike komponente. Oor die afgelope halfeeu is dit, wat die vormlike betref, reeds ingrypend gewysig deur die oorgang van 'n oorwegend plattelandse na 'n omvattende stedelike bestaans- en lewenswyse. Selfs die landelike is diep beïnvloed uit die stedelike sentra. Die boer is vandag nie meer so ontuis in die stad as vroeër nie. Die stad het nie meer plattelands geword nie - eerder nog meer grootstads maar die platteland het toenemend verstedelik. Die sosiokulturele afstand tussen stad en platteland het byna verdwyn, en die verskille is feitlik uitgewis.

Dit kan met 'n groot mate van sekerheid voorspel word dat die Afrikaanse volk in die komende dekades verder gedifferensieerd sal raak, horisontaal sowel as vertikaal, in beroepsgroepe en sosiale klasse, in status en leefwyse met 'n gepaardgaande en groeiende spesialisasie en sofistikasie. Ook in godsdiens en lewensbeskouing. Hiermee word bv. in die praktyk nie genoegsaam rekening gehou by die aanbieding van programme vir die viering van volksfeeste nie. Dit word 
dikwels ook sonder die nodige realisme veroordeel as snobisme of dit motiveer pleidooie dat klassevorming teengegaan moet word. Die noodwendige effek hiervan op die kultuuruitinge blyk o.a. uit die verandering t.o.v. organisasie en kultuurbelewenis. Die debats- en kultuurvereniginge van 1929 - wat die wese van die F.A.K. gevorm het - het plek gemaak vir algemene kunsvereniginge, vir die Rapportryersorganisasie met sy selektiewe aard, rolprent en toneelpremiêres; staatsgesubsidieerde toneelgroepe staan naas of in die plek van die reisende amateurgroepe van weleer en lg. streef na steeds groter sofistikasie en professionele standaarde.

Groter kontak met nie-Afrikaanse kultuurgemeenskappe is veel groter as tevore. Die betreklike skeiding tussen Afrikaans- en Engelssprekendes in Suid-Afrika deurdat eg. oorwegend plaas- en lg. oorwegend stadsbewoners was, het plek gemaak vir toenemende kontak deur die Afrikaner se verstedeliking. Ons noodsaaklike toetrede tot die ekonomiese terrein het onafwendbaar gelei tot vermeerderde en intensiewe kontak met alle nie-Afrikaanse kultuurgemeenskappe. Dit geld trouens ook die toetrede tot die beroepslewe. Die kommunikasiemiddele - film, pers, radio en een of ander tyd ook televisie - bring die Amerikaanse kultuur regstreeks tot binne ons huise. Die status wat die Amerikaanse beskawing geniet t.g.v. prestasies op tegnologiese, wetenskaplike en politieke gebied maak dit onvermydelik. Die relatiewe numeriese geringheid van die Afrikaner - in vergelyking met die Amerikaanse getalle - en die gepaardgaande gebrek aan middele bring teweeg dat ons prestasies, hoe kwalitatief hoogstaande eintlik nooit vergelyk kan word nie. Ons kan eenvoudig nie dieselfde volume aan films, aan publikasies, aan radio- of aan televisiemateriaal lewer as die V.S.A. nie. En wat ons lewer word dikwels nog op die agtergrond gedruk deur die besondere bejeëning van Suid-Afrika op die politieke vlak.

Eweso word die Afrikaanse kultuur in toenemende kontak gebring met ander kulture deur die koms van groot getalle immigrante. Hulle assimilasie en verafrikaansing word teengewerk deur die feit dat hulle 'n keuse het in Suid-Afrika: om of by die Afrikaanse of by die Engelse kultuurgroep in te skakel. Met die Engelse kultuur as die een wat die hoogste status geniet, is die keuse betreklik maklik en ook betreklik 
eensydig. Daaruit sou geredeneer kan word dat die Afrikaanse kultuur derhalwe minder blootgestel word aan 'n vreemde beinvloeding van binne deur opname. Dit is slegs gedeeltelik en tydelik waar. Die gevolg van die situasie is dat die Afrikaanse kultuur wat homself eintlik hoofsaaklik versterk deur eie aanwas, steeds gekonfronteer word met die aanwesigheid van 'n sterk nie-Afrikaanse kultuurgemeenskap.

Die tema nl. die Afrikaanse volkskultuur en die nuwe wêreld, kan herlei word tot die situasie wat Herder reeds beskryf het, waarin ' $n$ volkskultuur beland tussen isolasie en innovasie. Mühlmann het die problematiek geformuleer as die spanning tussen Volkstum und Zivilisation. Volgens Herder is 'n volk nie volkome sonder oorname van kultuur van ander volke nie, terwyl die oorname juis die eie identiteit kan vernietig. In 'n wêreld van verinnigte kommunikasie en kontak word hierdie spanning steeds sterker. Geen volk, ook nie die Afrikaner kan kultureel groei sonder beskawingsoorname of kulturele ontlening nie. Hierbo is reeds verduidelik hoe die Afrikaner se getallegeringheid en gepaardgaande gesamentlike ekonomiese vermoë beskawingsoorname op groot skaal bevorder.

Hierdie aspek verdien verdere aandag. Geen beskawingsgoedere is neutraal, bóvolks, supra-kultureel nie. Dit ontstaan as uitvindsels, ontdekkings, skeppinge binne een of ander volkskultuur. Sommige van die goedere dra minder van 'n nasionale en meer van ' $n$ universele stempel as ander. Die motor, die telefoon, die vliegtuig, sou as beskawingsgoedere kan versprei sonder om die onderskeie nasionale kultuurpatrone wesentlik te beïnvloed. Die boekdrukkuns met al die tegnologiese verbeterings daarop, die radiowese insluitende televisie, die fototegniek in al sy vorme tot by die rolprentfilm, dra 'n ander karakter. Met die oorname van sodanige tegnologiese beskawingskomponent word terselfdertyd 'n groot deel van die nasionale kultuur waaruit dit ontspring het, oorgeneem. Die ontvangende kultuur staan derhalwe voor die keuse om die beskawingsgoed met sy oorspronklike nasionale stempel huidjie en muidjie oor te neem of dit te verwerk deur die vroeëre nasionale cachet wat dit deur gebruik in die uitvinderskultuur verkry het, eers te verwyder en sy eie daarop te plaas. Laasgenoemde proses is nie so maklik nie. 
Die boekdrukkuns met al sy toevoegings tot die allernuutste ontwikkelinge is in Suid-Afrika geen onbekende nie. Maar in hoeverre het ons reeds daarin geslaag om bv. op ons koerantwese 'n Afrikaanse stempel af te druk, daaraan 'n inhoud gegee ooreenkomstig die fundamentele waardes, sy dit dan ook maar net verstaan in die lig van die Christendom in die algemeen? Miskien het ons beter geslaag op die gebied van die radiowese. Met betrekking tot televisie sal dit m.i. moeiliker gaan juis omdat $\mathrm{lg}$. groter eise aan mensemateriaal en middele stel. Hierdie probleem word veral duidelik geillustreer deur die posisie van die filmbedryf. Niemand sou iets teë kan hê op ons oorname van die tegnologiese aspekte van die rolprentkamera en die rolfilm nie. Maar al ons dappere pogings ten spyt kan ons mannekrag en finansiële vermoë nie die volume (en miskien die kwaliteit) lewer om in die land se vermaaklikheidsbehoeftes te voorsien nie.

Die nuwe wêreld waarvan in die opskrif sprake is, kan kortliks aangedui word as 'n wêreld van om- en oorspannende kommunikasie, al bereik die beste middele nie noodwendig altyd werklike kommunikasie nie. Dit is 'n wêreld van krimpende formaat deurdat al groter afstande in al korter tyd afgelê word. Dit is ' $n$ wêreld wat in die lig van die twee genoemde omstandighede die uitwissing van verskeidenhede beleef en bevorder en wat reeds probeer om vooruit te gryp op die droom van 'n volklose mensheid met die minimum van kultuuronderskeidinge. Tog het hierdie wêreld, histories gesien, ook groter geword. Dit is nie meer beperk tot die Chinese ryk of die Midde-Oosterse gebied, tot die Romeinse imperium of tot Wes-Europa nie. Dit is aarde-omspannend en kosmies gerig in sy strewe om die sterreruimte te inkorporeer. Dit het min geduld met die kleine in sy haas om die grote te ken en te beheer. Dit is meteen ook 'n wêreld van toenemende sekularisme in die sin van bevryding of ontvlugting van 'n geopenbaarde religie wat objektiewe norme stel, na 'n onbewuste aanvaarding van 'n mensgemaakte subjektiewe religie met relatiewe norme.

In hierdie wêreld verkeer die Afrikaanse volk met sy jong kultuur en met hierdie wêreld sal hy altyd meer gekonfronteer word. Die proses van kulturele toenadering, indien nie van kulturele eenderswording nie, kan nòg ons, nòg enige ander volk ontloop. Om dit te probeer doen sal wees om met 
die hakskene teen die prikkels te skop. Soos in die geval van alle ander volke is dit die gelowige deel van ons volk se roeping om 'n eie kulturele „ekumene”, gegrond op die waarheid, te vorm in onderskeiding van die Babelse dwangeenheid en in groeiende ontbloting van die antitese maar saam met ander gelowige volke, d.w.s. saam met die gelowige dele van ander volke.

Teen die agtergrond van hierdie eenderswordende wêreld is dit te verwagte en reeds baie duidelik waarneembaar, dat die Afrikaanse volkskultuur in al sy sektore, in sy uitinge en skeppinge en prosesse, in die letterkunde, wetenskap, kuns, politiek, vermaaklikheid en bedryf toenemend in 'n buiteAfrikaanse sfeer beweeg, daarvan oorneem en dit in die liggaam van die volkskultuur indra. Die vraag is: hoe vind die sintese plaas?

Teenoor die nuwe wêreld om ons en in ons midde staan die Afrikaanse volkskultuur m.i. in die eerste plek gekonfronteer met die roeping om sy nuutverworwe beskawingsmateriaal te verwerk tot 'n eie patroon in harmonie met die basiese lewenswaardes van die volk. 'n Bydrae na buite is ondenkbaar sonder sodanige omskepping. Die struikelblokke wat die Afrikaanse kultuur moet oorkom in sodanige aktiwiteit is reeds aangedui: geen homogene belydenisgrondslag nie, klein getalle, 'n onbekende taal, gebrekkige geldelike middele, 'n dubieuse status in die wêreld.

Hierdie moedontnemende omstandighede maak 'n besondere appèl op die gewete en die geloof van die Calvinis. Die Calvinisme is by uitstek die lewens- en wêreldbeskouing van swak en klein en ootmoedige mense wat tog sterk is in hulle ruepingsbewustheid. Morley se gevleuelde woorde in sy biografie van Cromwell is hier ter sake: "Calvinism has proved itself a famous soil for rearing heroic natures". Ook Wilhelm Mühlmann se standpunt oor die ,historiese gewig" ten opsigte van die kultuurskepping en -handhawing, is van toepassing. Alle volkslede dra nie ewe veel by tot nuutskeppinge, tot vormgewing of tot handhawing van die volkskultuur nie. Sommige se aandeel is groter as ander s'n vanweë hulle status en/of persoonlikheid. "Calvinism", volgens Morley, „exalted its votaries to a pitch of heroic moral energy that has never been surpassed". Mense word nie Calviniste omdat hulle sterk is nie; die mens, wat 'n arme wurm is, word 
sterk wanneer hy Calvinis word. Daarom kan hy meer as 'n gemiddelde deel bydra.

Vir daardie deel van die Afrikanerdom wat Christeliknasionaal verstaan as Calvinisties-Afrikaans, is die verdeeldheid, die geringheid en die teenkanting 'n uitdaging. Dit bring hom juis tot die roeping om te herstel. By al die negatiewe faktore is een in sy guns: die historiese rol van die Gereformeerde religie in die vorming van die Afrikaanse tradisie hoe afgedun en verswak, verwater en verbleik dit ook al mag wees. Op hierdie volksdeel se skouers rus die roeping om die vrugte van die twintigste eeu se beskawing wat uit die tuine van ander volke gepluk kan word, te verwerk tot Calvinisties-Afrikaanse kultuurprodukte en om die wêreld te konfronteer met hierdie vernieude kultuurkomponente. Die Calvinis sal dit doen met die eskatologiese kennis, van die groter uitwendige en selfs prinsipiële eenderswording van die wêreld, dat die beskawingsontwikkeling besig is om te lei tot 'n amperse wêreldkultuur. Tog sal die antitese ook groter word en sal die nasionale kulturele verskeidenheid bly bestaan, hoewel in kleiner mate, ook in die sin van die besef van etniese verskeidenheid nieteenstaande nouliks waarneembare kultuuronderskeiding.

Wat die Afrikaner-Calvinis op kultuurgebied nuutskeppend, omvormend en reformerend gaan voortbring, gaan uit die aard van die saak Afrikaans wees. Dit sal nie dié Afrikaanse volkskultuur wees in die $\sin$ van die enigste, moontlik selfs nie die mees verteenwoordigende rigting in die Afrikaanse kultuur nie. Nogtans sal dit deel van die Afrikaanse kultuur wees waarmee die Afrikaanse Calvinis tot sy volk en tot die volke van die wêreld spreek. Hierby moet egter ook die ontstellende feit in aanmerking geneem word dat dit selfs in botsing en in antitese met die breër en algemene Afrikaanse volkskultuur sal wees. Dit bevat ook die troos dat dit die permanente doel van sy volksbestuur is.

Die Calvinistiese Afrikaner is daartoe geroepe om aan die begrip Christelik-nasionaal 'n spesifieke en konkrete inhoud te gee deur sy vormgewing aan die kuns, aan die bedryf, aan die onderwys, aan die kommunikasiewese, aan die vermaaklikheidswese, aan die politiek. Dit moet die komponente van 'n Christelik-nasionale, d.w.s. 'n CalvinistiesAfrikaanse lewensstyl wees wat as model vir die Afrikaanse 
volkskultuur moet dien - 'n model wat sy navolging sal vind maar wat ook teenstand en verguising van die kant van volksgenote sal ervaar, veel meer nog as wat tans reeds sporadies die geval is.

Die Afrikaanse volkskultuur het nog nie sy finale afronding bereik nie, ook nie sy einde nie. Dit moet nog steeds verder veranderend gehandhaaf en suiwerend gebou word. P.U. vir C.H.O.

J. H. Coetzee. 